\title{
Poly(5-vinylbenzothiadiazole) for High-Performance Lithium-Ion Batteries
}

Ling Chen, ${ }^{\S, 1}$ Colin R. Bridges, ${ }^{\S, 2}$ Guangyuan Gao, ${ }^{1}$ Thomas Baumgartner, ${ }^{\star, 2}$ and Xiaoming $\mathrm{He}^{*, 1}$

${ }^{*}$ To whom correspondence should be addressed

\$These authors contributed equally to this work

${ }^{1}$ School of Chemistry and Chemical Engineering, Shaanxi Normal University, Xi'an 710119, P. R. China

${ }^{2}$ Department of Chemistry, York University, 4700 Keele Street, Toronto, Ontario M3J 1P3, Canada

*Corresponding Author Email: xmhe@snnu.edu.cn, tbaumgar@yorku.ca 
Table S-1. Crystal data and structure refinement for 5-vinylbenzothiadiazole.

\begin{tabular}{|c|c|}
\hline Empirical formula & $\mathrm{C}_{8} \mathrm{H}_{6} \mathrm{~N}_{2} \mathrm{~S}$ \\
\hline Formula weight & 162.21 \\
\hline Temperature & $283(2) \mathrm{K}$ \\
\hline Wavelength & $0.71073 \AA$ \\
\hline Crystal system & Monoclinic \\
\hline Space group & $\mathrm{P} 2_{1} / \mathrm{n}$ \\
\hline Unit cell dimensions & $\begin{array}{ll}a=7.906(4) \AA & \alpha=90^{\circ} \\
b=7.665(4) \AA & \beta=90.024(19)^{\circ} \\
c=12.668(6) \AA & \gamma=90^{\circ}\end{array}$ \\
\hline Volume & $767.7(7) \AA^{3}$ \\
\hline Z & 4 \\
\hline Density (calculated) & $1.403 \mathrm{Mg} / \mathrm{m}^{3}$ \\
\hline Absorption coefficient & $0.348 \mathrm{~mm}^{-1}$ \\
\hline $\mathrm{F}(000)$ & 336 \\
\hline Crystal size & $0.360 \times 0.210 \times 0.160 \mathrm{~mm}^{3}$ \\
\hline Theta range for data collection & 3.037 to $26.009^{\circ}$ \\
\hline Index ranges & $8 \leq h \leq 9,-9 \leq k \leq 9,-15 \leq l \leq 14$ \\
\hline Reflections collected & 6428 \\
\hline Independent reflections & $1512[\mathrm{R}$ (int) $=0.0371]$ \\
\hline Completeness to theta $=25.242^{\circ}$ & $99.7 \%$ \\
\hline Absorption correction & Semi-empirical from equivalents \\
\hline Refinement method & Full-matrix least-squares on $\mathrm{F}^{2}$ \\
\hline Data / restraints / parameters & $1512 / 0 / 100$ \\
\hline Goodness-of-fit on $\mathrm{F}^{2}$ & 1.057 \\
\hline Final $R$ indices [l>2sigma(I)] & $\mathrm{R}_{1}=0.0422, \mathrm{wR}_{2}=0.0959$ \\
\hline $\mathrm{R}$ indices (all data) & $\mathrm{R}_{1}=0.0626, \mathrm{wR}_{2}=0.1056$ \\
\hline Largest diff. peak and hole & 0.182 and -0.261 e. $\AA^{-3}$ \\
\hline
\end{tabular}


Table S-2. Bond lengths [Å] and angles [०] for 5-vinylbenzothiadiazole.

\begin{tabular}{|c|c|c|c|}
\hline \multicolumn{4}{|c|}{ Bond lengths $[\AA]$} \\
\hline$S(1)-N(1)$ & $1.610(2)$ & $\mathrm{C}(3)-\mathrm{H}(3)$ & 0.9300 \\
\hline$S(1)-N(2)$ & $1.612(2)$ & $C(4)-C(5)$ & $1.368(3)$ \\
\hline$N(1)-C(6)$ & $1.351(3)$ & $C(4)-C(7)$ & $1.465(3)$ \\
\hline$N(2)-C(1)$ & $1.339(3)$ & $C(5)-C(6)$ & $1.411(3)$ \\
\hline$C(1)-C(2)$ & $1.421(3)$ & $\mathrm{C}(5)-\mathrm{H}(5)$ & 0.9300 \\
\hline$C(1)-C(6)$ & $1.429(3)$ & $C(7)-C(8)$ & $1.318(3)$ \\
\hline$C(2)-C(3)$ & $1.349(3)$ & $\mathrm{C}(7)-\mathrm{H}(7)$ & 0.9300 \\
\hline $\mathrm{C}(2)-\mathrm{H}(2)$ & 0.9300 & $\mathrm{C}(8)-\mathrm{H}(8 \mathrm{~A})$ & 0.9300 \\
\hline$C(3)-C(4)$ & $1.437(3)$ & $\mathrm{C}(8)-\mathrm{H}(8 \mathrm{~B})$ & 0.9300 \\
\hline \multicolumn{4}{|c|}{ Bond angles $\left[^{\circ}\right]$} \\
\hline$N(1)-S(1)-N(2)$ & 101.43(9) & $C(3)-C(4)-C(7)$ & $121.3(2)$ \\
\hline$C(6)-N(1)-S(1)$ & $105.98(15)$ & $C(4)-C(5)-C(6)$ & $119.25(18)$ \\
\hline$C(1)-N(2)-S(1)$ & $105.94(16)$ & $\mathrm{C}(4)-\mathrm{C}(5)-\mathrm{H}(5)$ & 120.4 \\
\hline$N(2)-C(1)-C(2)$ & $127.1(2)$ & $\mathrm{C}(6)-\mathrm{C}(5)-\mathrm{H}(5)$ & 120.4 \\
\hline$N(2)-C(1)-C(6)$ & $113.8(2)$ & $N(1)-C(6)-C(5)$ & $126.37(19)$ \\
\hline$C(2)-C(1)-C(6)$ & $119.16(18)$ & $N(1)-C(6)-C(1)$ & $112.89(19)$ \\
\hline$C(3)-C(2)-C(1)$ & $118.47(19)$ & $C(5)-C(6)-C(1)$ & $120.75(19)$ \\
\hline $\mathrm{C}(3)-\mathrm{C}(2)-\mathrm{H}(2)$ & 120.8 & $C(8)-C(7)-C(4)$ & $126.5(2)$ \\
\hline $\mathrm{C}(1)-\mathrm{C}(2)-\mathrm{H}(2)$ & 120.8 & $\mathrm{C}(8)-\mathrm{C}(7)-\mathrm{H}(7)$ & 116.8 \\
\hline$C(2)-C(3)-C(4)$ & $123.0(2)$ & $\mathrm{C}(4)-\mathrm{C}(7)-\mathrm{H}(7)$ & 116.8 \\
\hline $\mathrm{C}(2)-\mathrm{C}(3)-\mathrm{H}(3)$ & 118.5 & $\mathrm{C}(7)-\mathrm{C}(8)-\mathrm{H}(8 \mathrm{~A})$ & 120.0 \\
\hline $\mathrm{C}(4)-\mathrm{C}(3)-\mathrm{H}(3)$ & 118.5 & $\mathrm{C}(7)-\mathrm{C}(8)-\mathrm{H}(8 \mathrm{~B})$ & 120.0 \\
\hline$C(5)-C(4)-C(3)$ & $119.31(18)$ & $\mathrm{H}(8 \mathrm{~A})-\mathrm{C}(8)-\mathrm{H}(8 \mathrm{~B})$ & 120.0 \\
\hline$C(5)-C(4)-C(7)$ & 119.4(2) & & \\
\hline
\end{tabular}

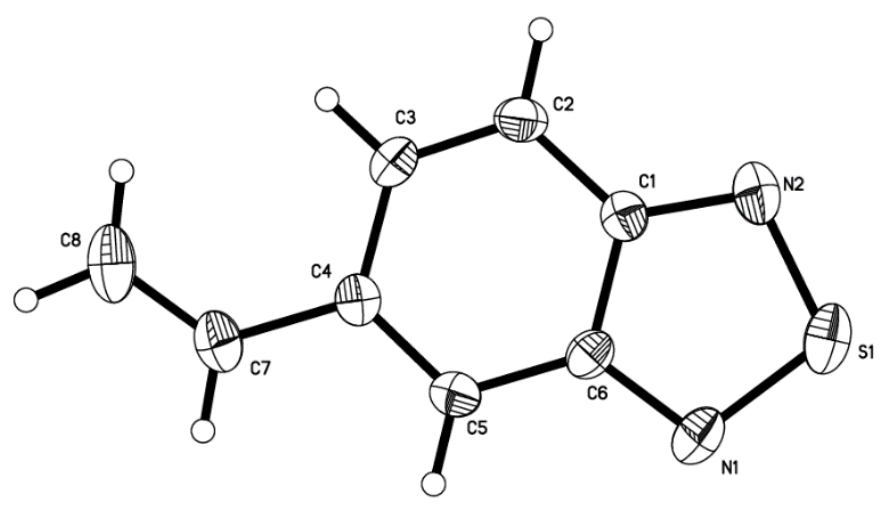




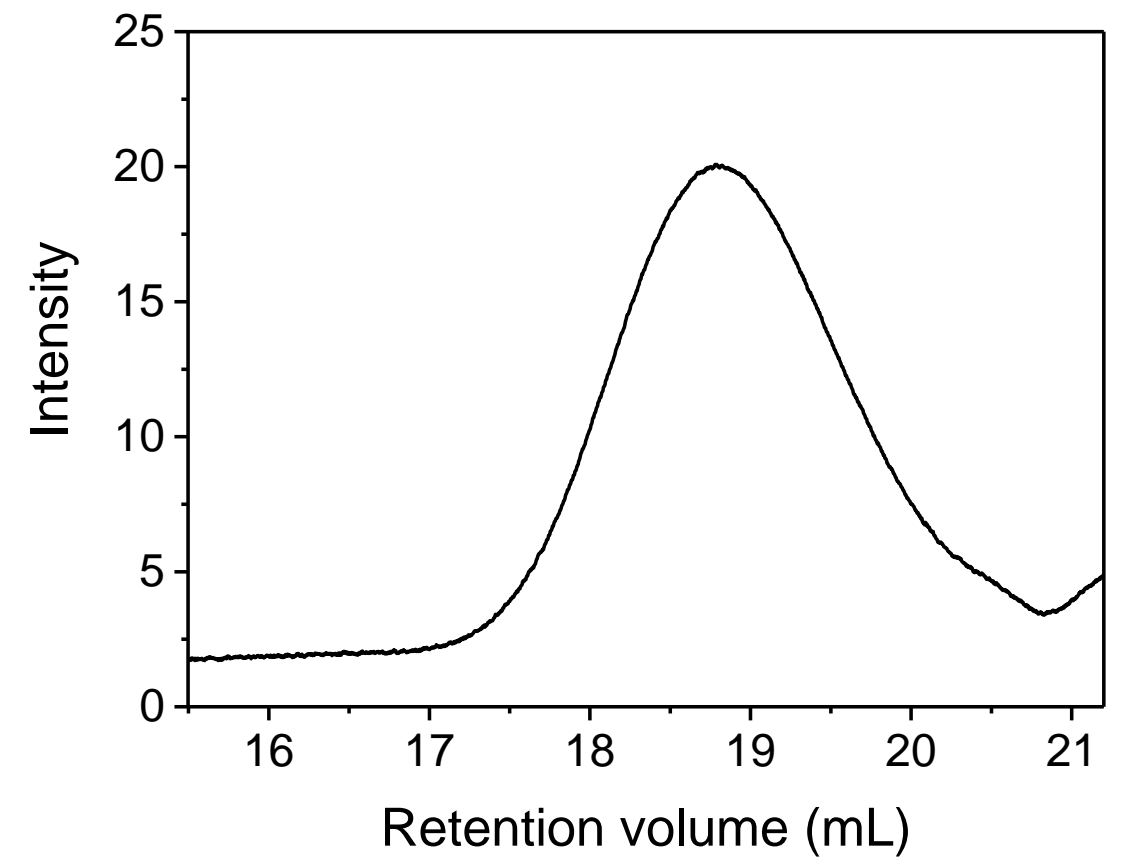

Figure S-1. GPC curve of poly(5-vinylbenzothiadiazole).

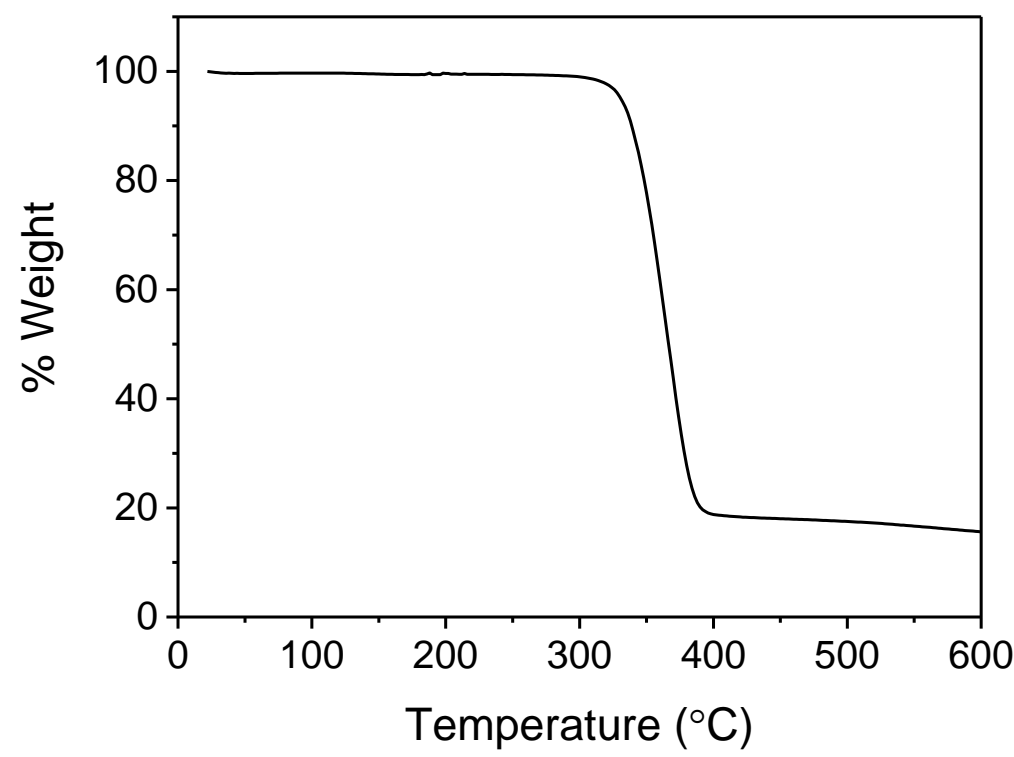

Figure S-2. Thermogravimetric analysis (TGA) for poly(5-vinylbenzothiadiazole). 


\section{DFT Calculations}

Theoretical calculations have been carried out through the Gaussian 09 software package. ${ }^{\mathrm{S} 1}$ Geometry optimization of the molecules, were carried out using the B3LYP/6-31G(d) level basis sets implemented in the Gaussian 09 software. Frequency analysis of all the molecules and intermediates contained no imaginary frequency showing that these are energy minima. The spin-density distribution calculation was augmented with a standard PCM solvation model using acetonitrile as a solvent.

(a)
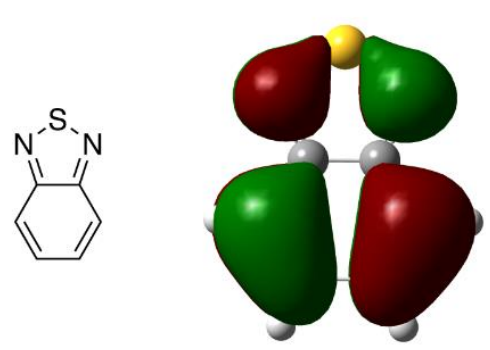

HOMO: $-6.62 \mathrm{eV}$

(b)

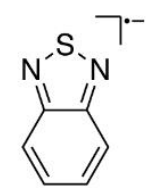

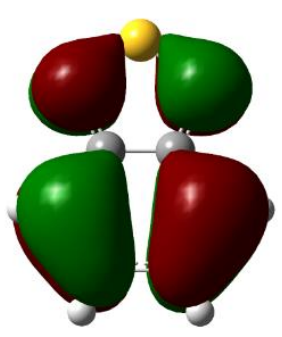

HOMO-1: $-5.47 \mathrm{eV}$

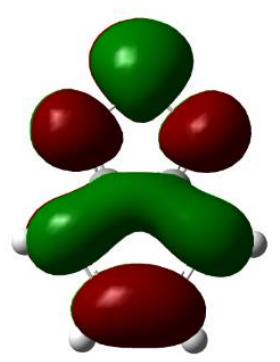

LUMO: $-2.40 \mathrm{eV}$

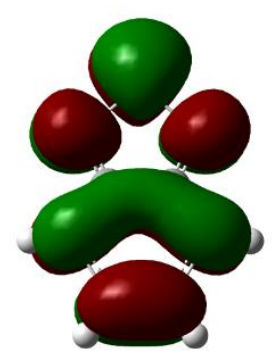

SOMO: $-2.71 \mathrm{eV}$

LUMO: -1.11 eV

(c)

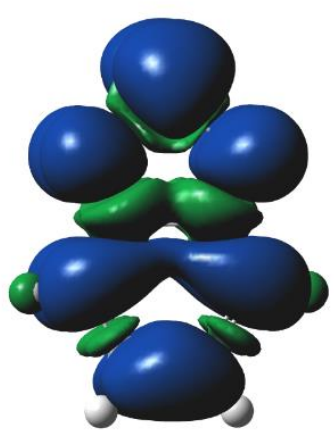

Figure S-3. Frontier orbitals and energies (B3LYP/6-31G(d) level of theory) for BTZ (a), BTZ- ${ }^{-}$(b), and spin density distribution in BTZ - (c); PCM solvation model, solvent: acetonitrile. ${ }^{\mathrm{S} 1}$ 

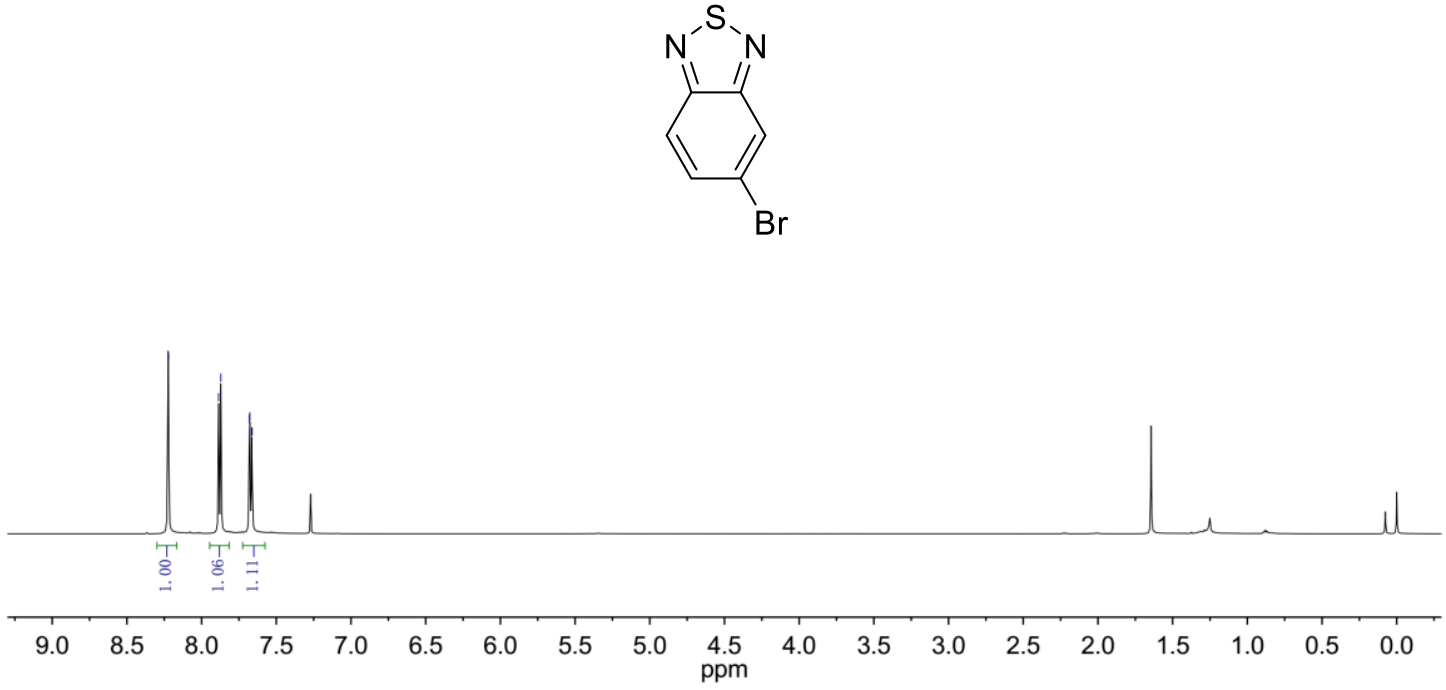

Figure S-4. ${ }^{1} \mathrm{H}$ NMR spectrum of 5-bromo-2,1,3-benzothiadiazole in $\mathrm{CDCl}_{3}$.
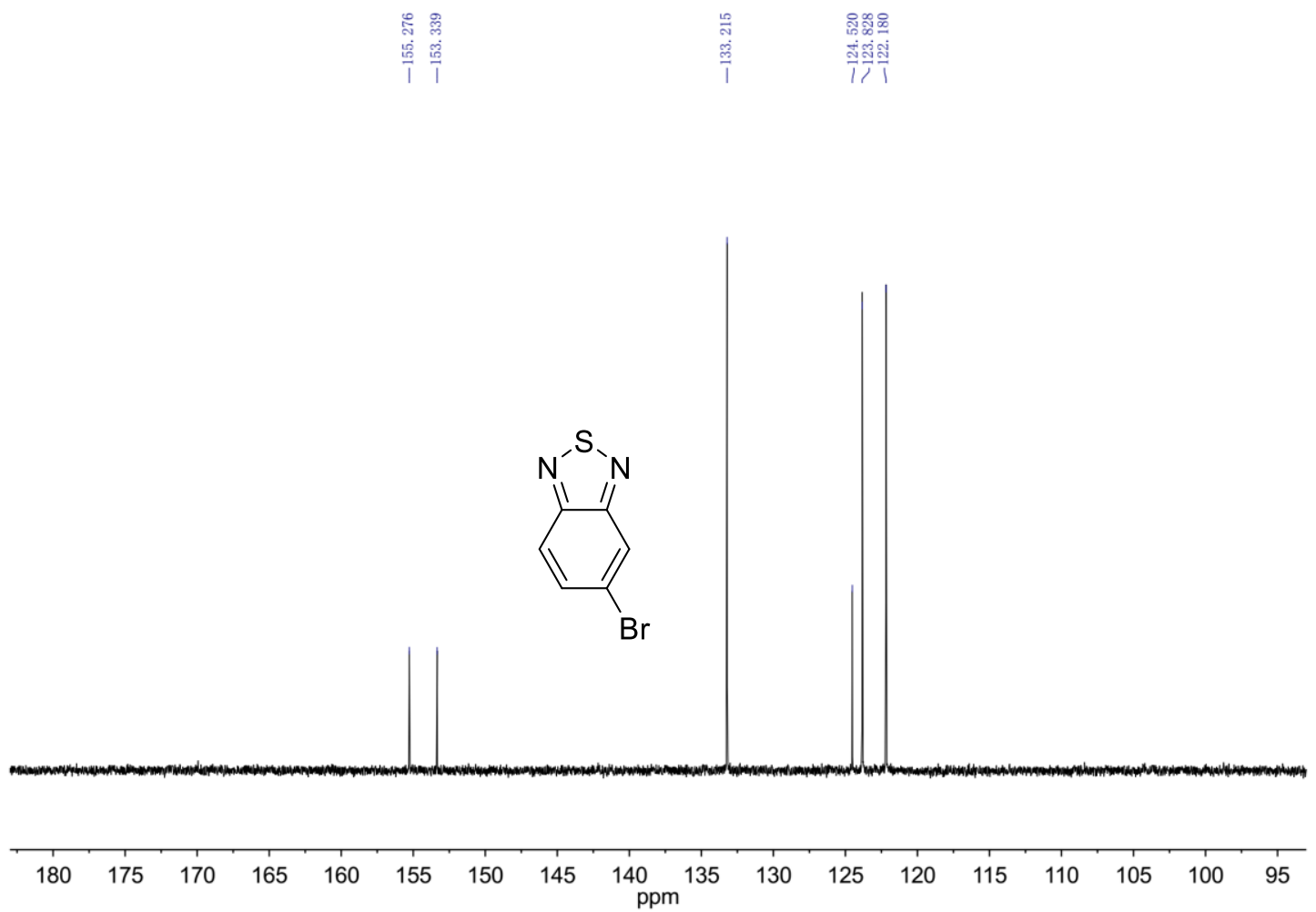

Figure S-5. ${ }^{13} \mathrm{C}\left\{{ }^{1} \mathrm{H}\right\}$ NMR spectrum of 5-bromo-2,1,3-benzothiadiazole in $\mathrm{CDCl}_{3}$. 


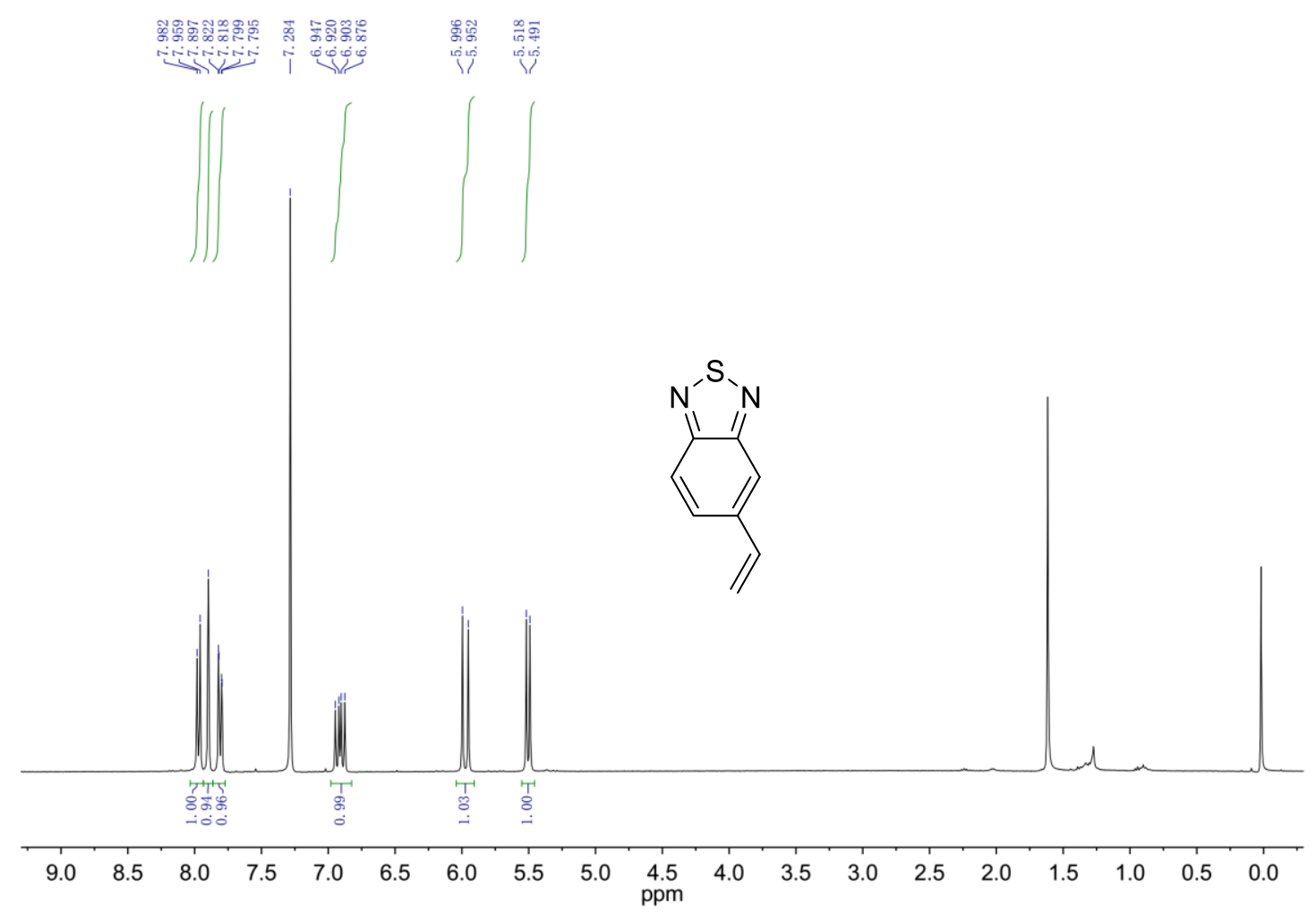

Figure S-6. ${ }^{1} \mathrm{H}$ NMR spectrum of 5-vinylbenzothiadiazole in $\mathrm{CDCl}_{3}$.

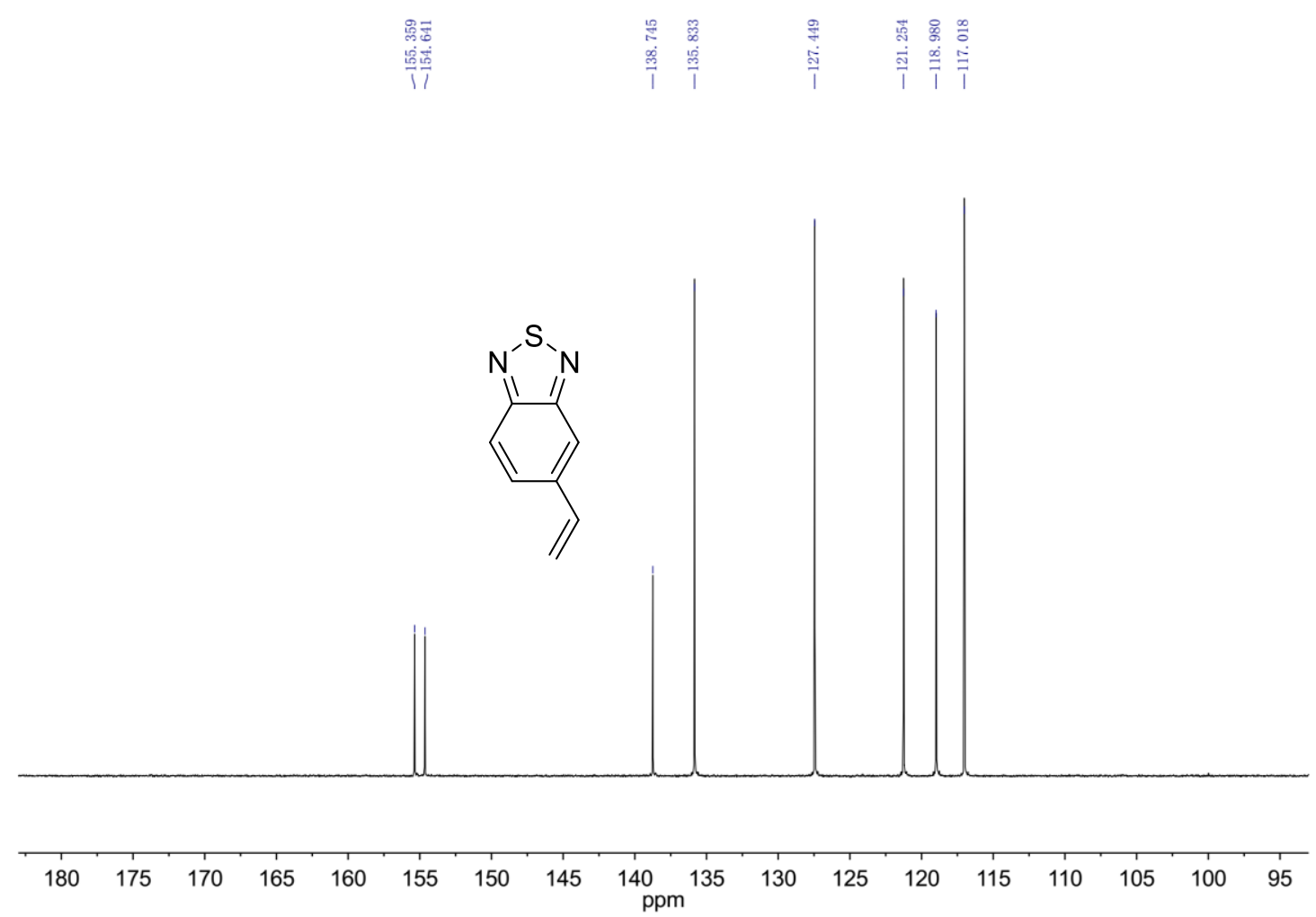

Figure S-7. ${ }^{13} \mathrm{C}\left\{{ }^{1} \mathrm{H}\right\}$ NMR spectrum of 5-vinylbenzothiadiazole in $\mathrm{CDCl}_{3}$. 


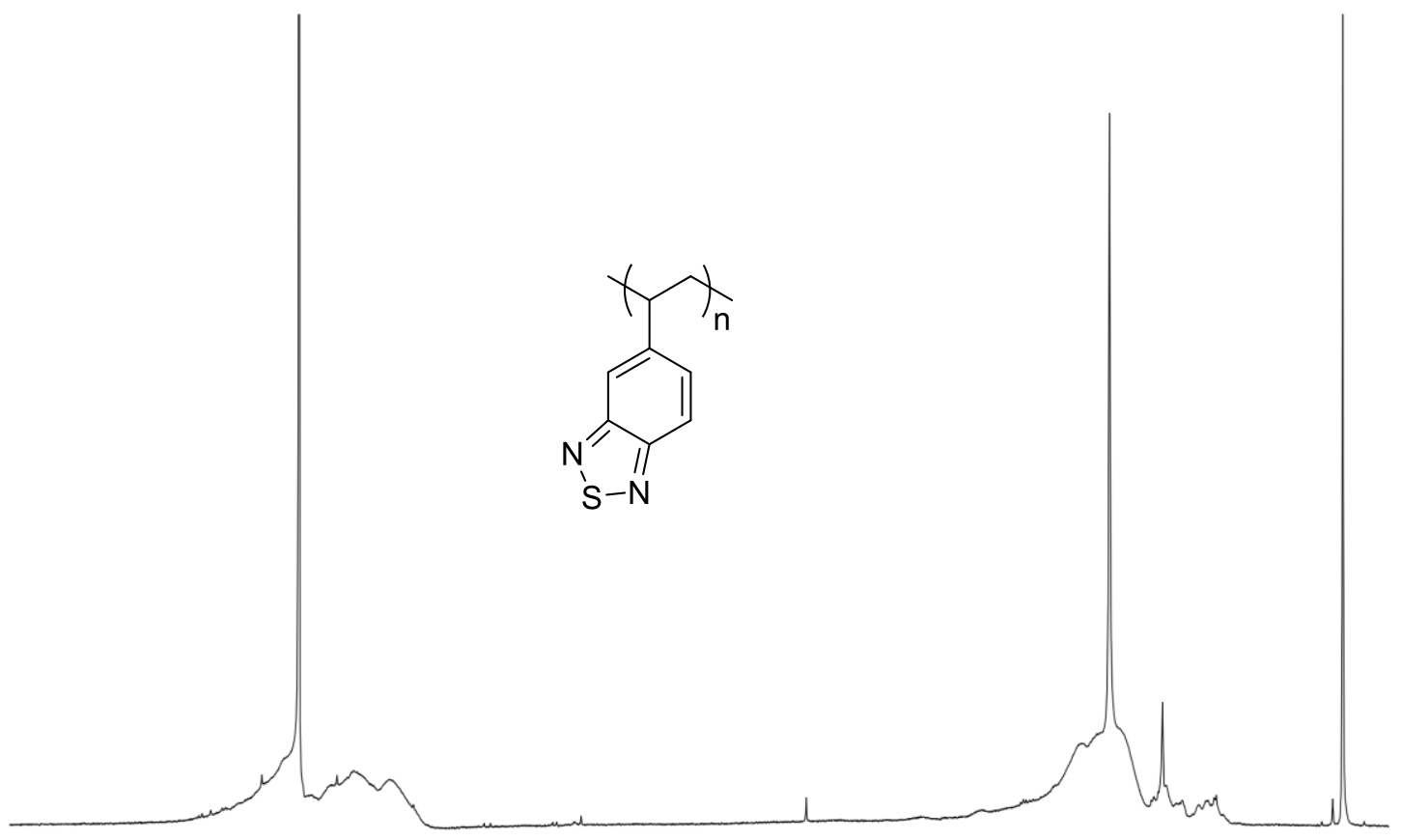

$\begin{array}{lllllllllllllllllll}9.0 & 8.5 & 8.0 & 7.5 & 7.0 & 6.5 & 6.0 & 5.5 & 5.0 & 4.5 & 4.0 & 3.5 & 3.0 & 2.5 & 2.0 & 1.5 & 1.0 & 0.5 & 0.0\end{array}$

Figure S-8. ${ }^{1} \mathrm{H}$ NMR spectrum of poly(5-vinylbenzothiadiazole) in $\mathrm{CDCl}_{3}$.

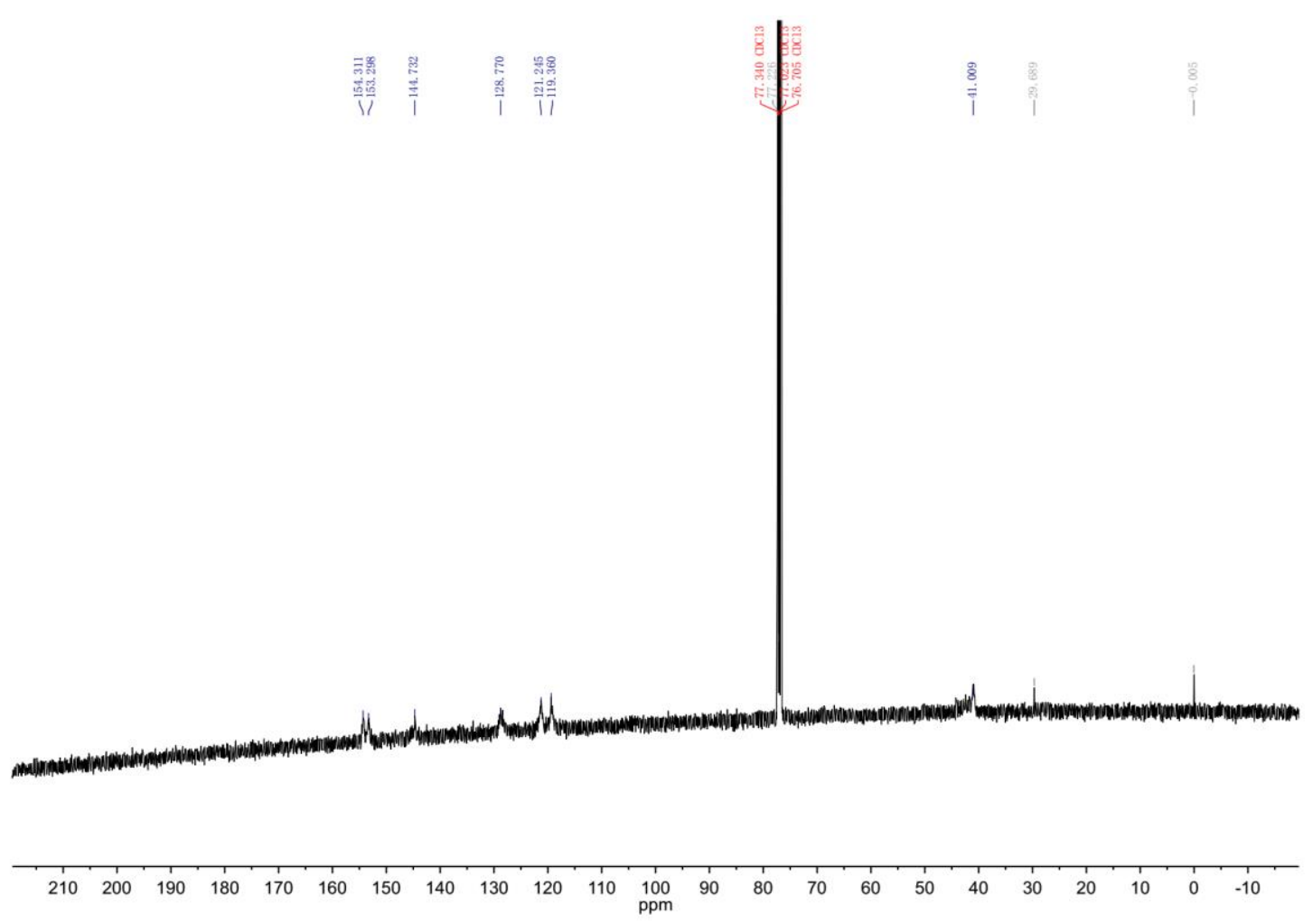

Figure S-9. ${ }^{13} \mathrm{C}\left\{{ }^{1} \mathrm{H}\right\}$ NMR spectrum of poly(5-vinylbenzothiadiazole) in $\mathrm{CDCl}_{3}$. 


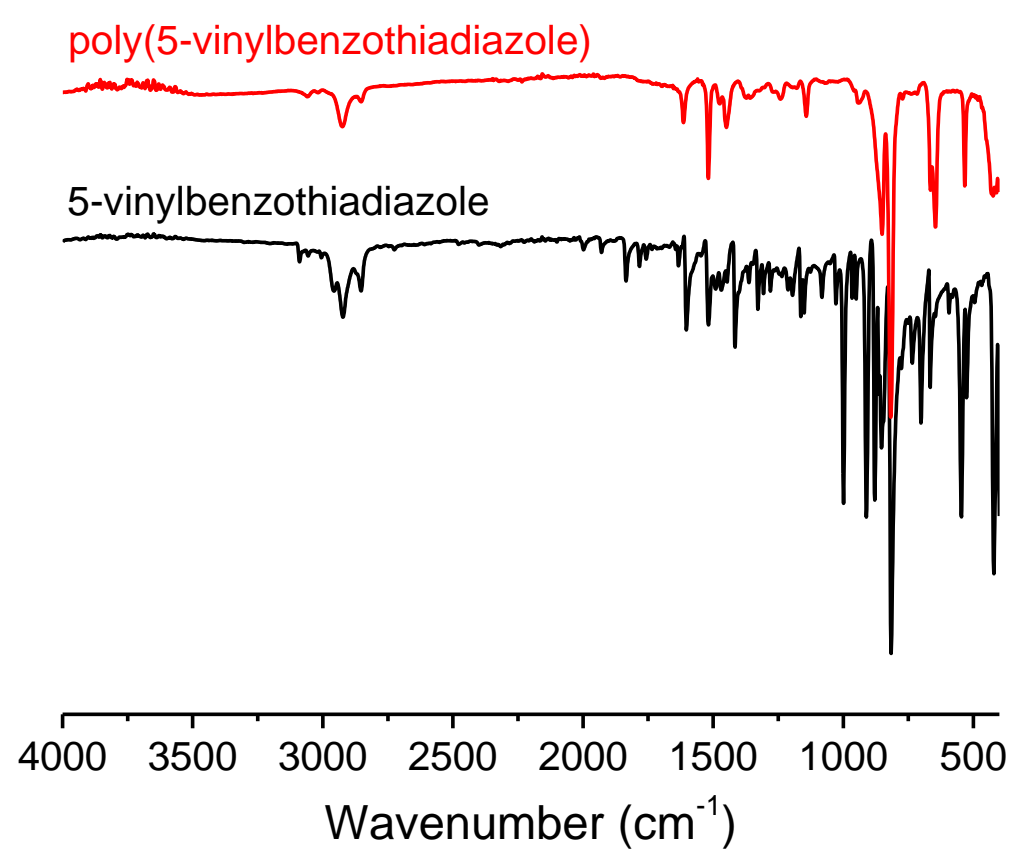

Figure S-10. IR spectra of poly(5-vinylbenzothiadiazole) and 5-vinylbenzothiadiazole.

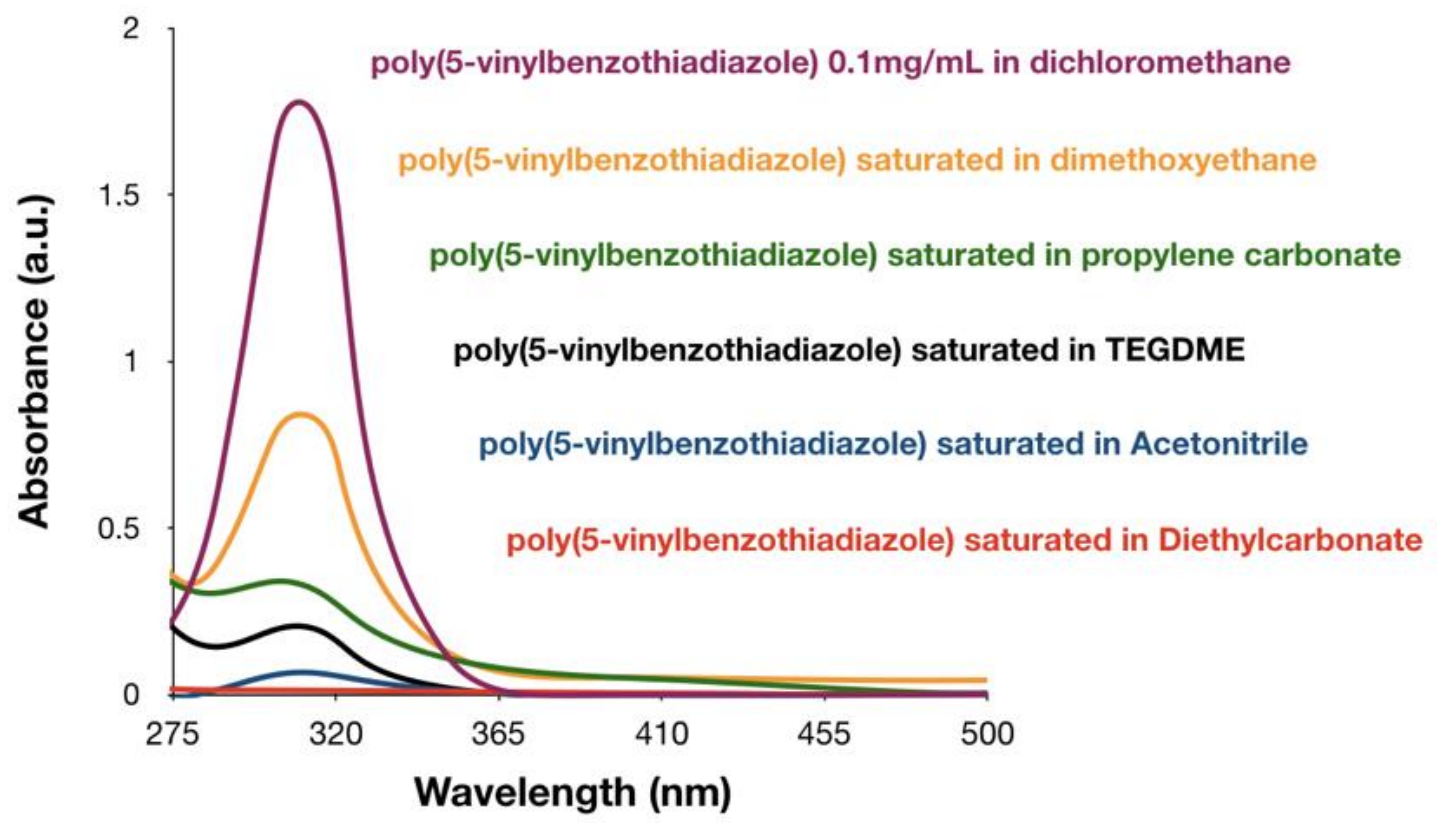

Figure S-11. UV-vis absorption spectroscopy showing low solubility of poly(5vinylbenzothiadiazole) in common battery electrolytes compared to a sample of the polymer dissolved in dichloromethane at $0.1 \mathrm{mg} / \mathrm{mL}$. An excess of the polymer was dissolved in each solvent, and left to stir for 24 hours to saturate the solution. The solution was then pushed through a syringe filter and put directly into a cuvette for measurement. The maximum solubility is well below $0.1 \mathrm{mg} / \mathrm{mL}$ in common electrolyte solvents. 


\section{Cyclic voltammetry on PBTz battery full range}

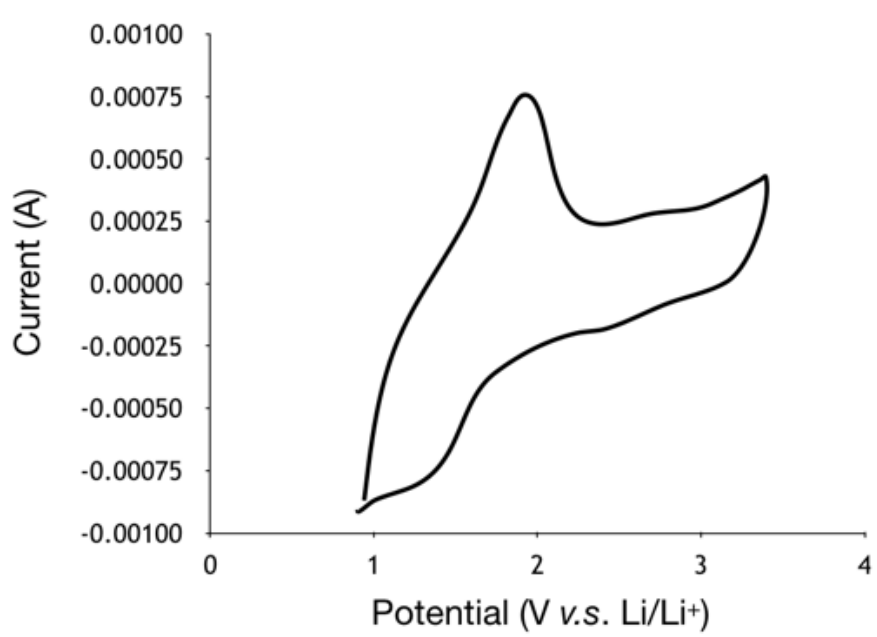

Figure S-12. Cyclic voltammetry on a poly(5-vinylbenzothiadiazole)/Li ion battery scanned across the entire charge/discharge potential range. Electrolyte is $1 \mathrm{M}$ LiTFSi in TEDGME, Anode is Li foil, Cathode is 1:1:1 PBTz:MWNT:PVDF, Scan rate is $2 \mathrm{mv} / \mathrm{s}$.

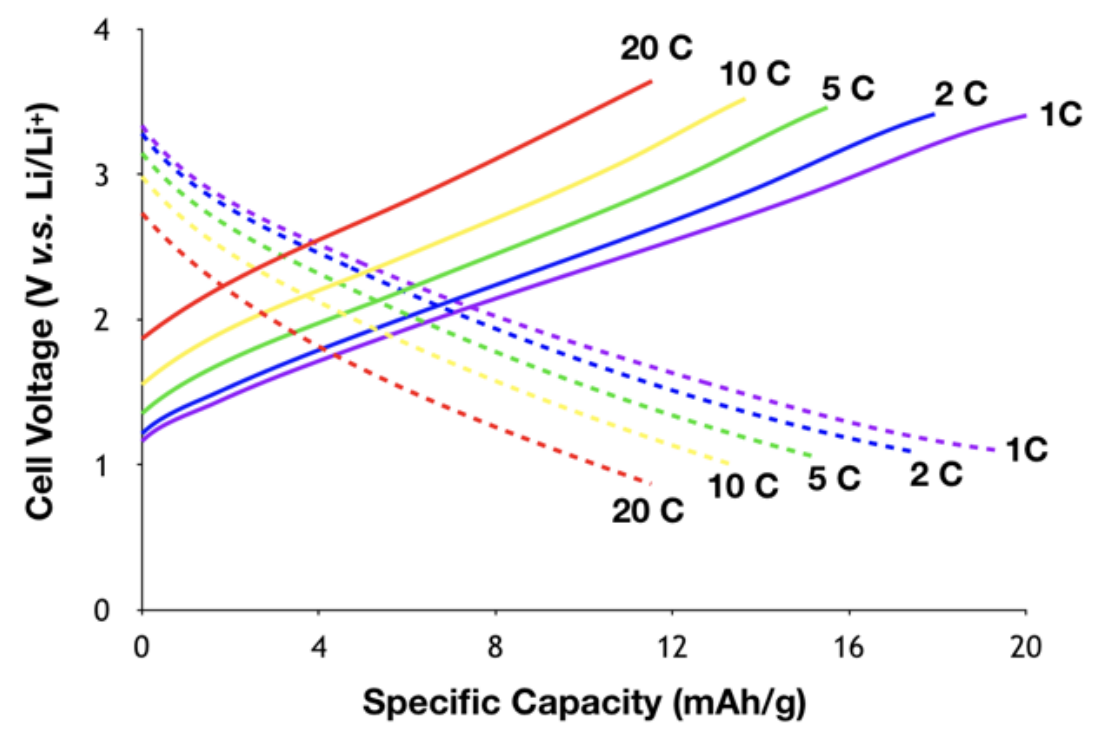

Figure S-13. Charge/discharge profiles of a battery consisting of SWCNT and PVDF in equal ratios. Current densities at the different $C$ rates are similar to the current densities of the batteries tested, ranging from $94 \mathrm{~mA} / \mathrm{g}$ at $1 \mathrm{C}$ to $1890 \mathrm{~mA} / \mathrm{g}$ at $20 \mathrm{C}$. The capacity contribution from the SWCNT to the total capacity of the battery is around 12$20 \mathrm{~mA} / \mathrm{g}$, reflecting about $13 \%$ of the total battery capacity at $1 \mathrm{C}$. 

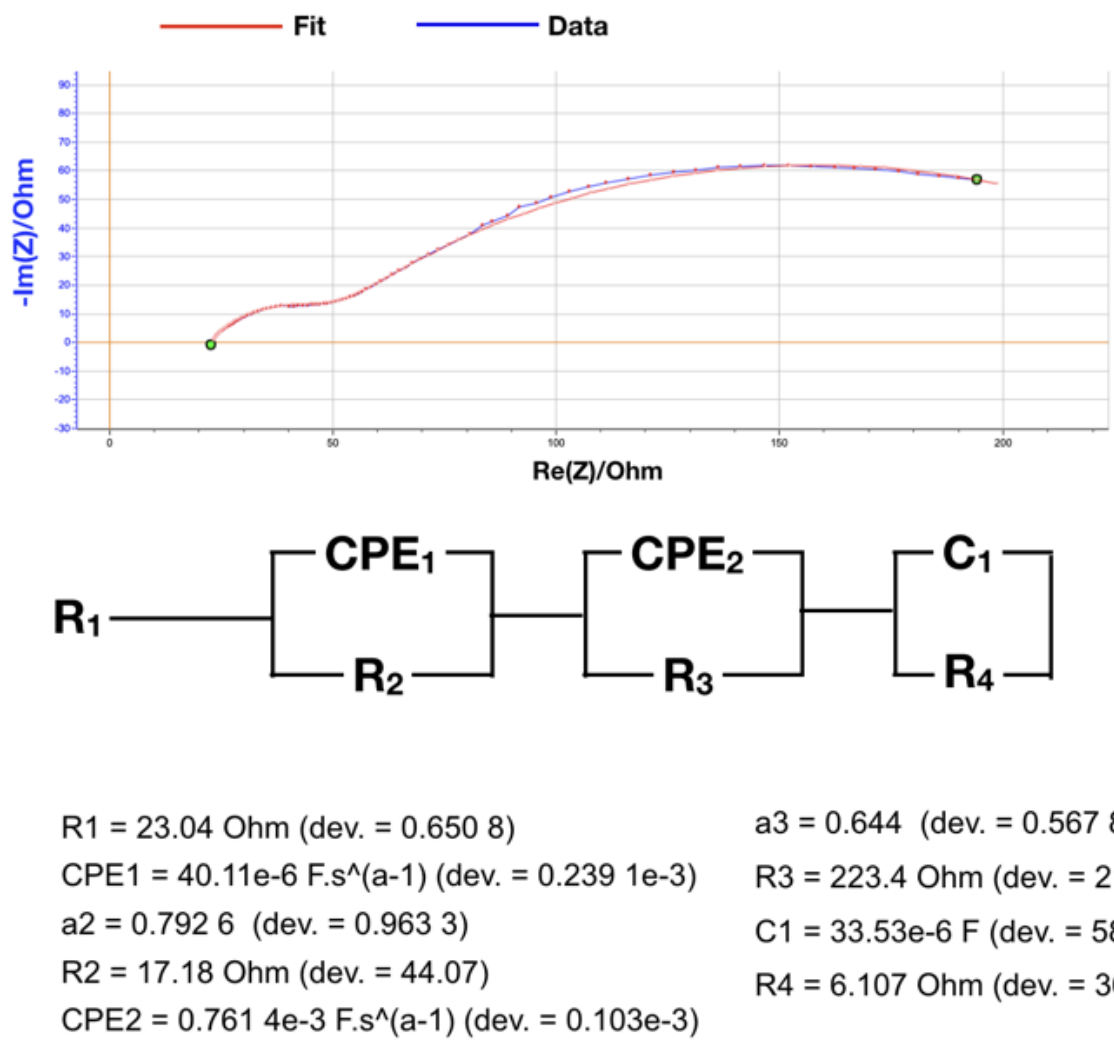

Figure S-14. Impedance spectroscopy data for poly(5-vinylbenzothiadiazole) batteries, along with the equivalent circuit and relevant circuit component properties. We attribute CPE 1 to the carbon nanotubes and $\mathrm{C} 1$ to the carbon coated copper electrode. Both the capacitance and resistance of these elements are similar to that of metallic carbon. We attribute the CPE 2 element to our poly(5-benzothiadiazole), which has a much higher capacitance and resistance. It can be seen that the majority (95\%) of the capacitance comes from poly(5-benzothiadiazole). 

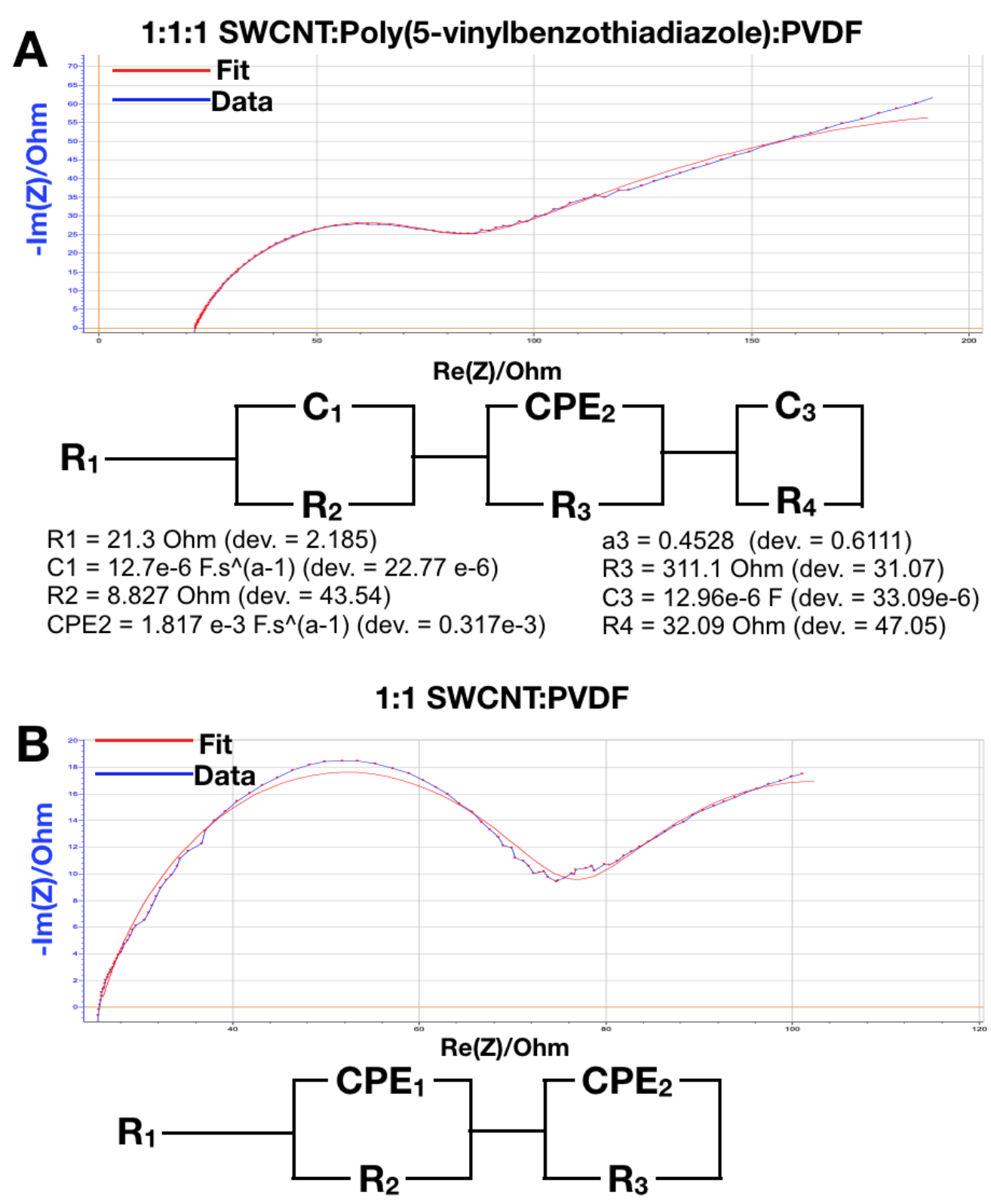
$\mathrm{R} 1=25.75 \mathrm{Ohm}(\mathrm{dev} .=0.3081)$
CPE2 = 5.32 e-3 F.s^(a-1) $($ dev. = 3.979 e-3)
CPE1 $=52.37$ e-6 F.s^$(a-1)($ dev. $=22.31$ e-6) a3 $=0.6892($ dev. $=0.7933)$
a2 $=0.7558($ dev. $=0.5661)$
$\mathrm{R} 2=50.04 \mathrm{Ohm}(\mathrm{dev} .=1.835)$
$\mathrm{R} 3=54.73 \mathrm{Ohm}(\mathrm{dev} .=25.2)$

Figure S-15: Impedance spectroscopy data for a 1:1:1 SWCNT:poly(5 vinylbenzothiadiazole):PVDF battery on $\mathrm{C} / \mathrm{Cu}$ electrodes $(\mathrm{A})$ and a $1: 1$ SWCNT:PVDF battery on C/Cu electrodes (B). Equivalent circuit diagrams and circuit component properties are listed below.

Discussion: Impedance spectroscopy on 1:1:1 SWCNT:poly(5 vinylbenzothiadiazole):PVDF (Figure S15 A): We attribute C1/R2 to the carbon nanotubes and C3/R4 to the carbon coated copper electrode. Both the capacitance and resistance of these elements are of similar magnitude to that 
of other carbon materials. The larger capacitance of CPE1 (in figure S15 B) is consistent with the larger amount and surface area of the carbon nanotube layer in this device. When PVDF is present it is conceivable that CPE 1 decreases due to a modification of the interface, while the parameters assigned to the carbon coated copper electrode remain constant with or without the PVDF layer. We attribute the CPE 2/R3 element to our poly(5-benzothiadiazole), which higher capacitance and resistance values that are expected for organic materials. This circuit assignment is supported by the EIS under identical conditions on a battery made of 1:1 SWCNT:PVDF (i.e. lacking the organic charge storage material) in figure S12 B. This data is accurately modelled the same circuit minus the CPE 2/R3 element attributed to the organic material, with the remaining resistance values being similar to our previously measured carbon nanotubes and carbon coated copper electrode. This, along with our battery data for a 1:1 PVDF:SWCNT electrode show that the majority (85-95\%) of the capacitance comes from poly(5-benzothiadiazole).

EIS was conducted on the fully assembled batteries using a voltalab PGZ 402. DC voltage $1700 \mathrm{mV}$ versus $\mathrm{Li}^{\prime} \mathrm{Li}^{+}$, driving AC voltage is $20 \mathrm{mV}$, data is scanned from $100 \mathrm{kHz}$ to $1 \mathrm{~Hz}$ with a data integration time of $1 \mathrm{~s}$. 
Table S-3. Cartesian coordinates for DFT-minimized structure of BTZ.

\begin{tabular}{|c|c|c|c|c|c|}
\hline \multirow{2}{*}{$\begin{array}{l}\text { Center } \\
\text { Number }\end{array}$} & \multirow{2}{*}{$\begin{array}{l}\text { Atomic } \\
\text { Number }\end{array}$} & \multirow{2}{*}{$\begin{array}{l}\text { Atomic } \\
\text { Type }\end{array}$} & \multicolumn{3}{|c|}{ Coordinates (Angstroms) } \\
\hline & & & $x$ & $\mathrm{Y}$ & Z \\
\hline 1 & 6 & 0 & -0.000137 & -2.411091 & 0.716651 \\
\hline 2 & 6 & 0 & -0.000137 & -2.411091 & -0.716651 \\
\hline 3 & 6 & 0 & 0.000307 & -1.246645 & -1.439837 \\
\hline 4 & 6 & 0 & -0.000102 & -0.013056 & -0.725847 \\
\hline 5 & 6 & 0 & -0.000102 & -0.013056 & 0.725847 \\
\hline 6 & 6 & 0 & 0.000307 & -1.246645 & 1.439837 \\
\hline 7 & 1 & 0 & -0.000450 & -3.365638 & 1.235534 \\
\hline 8 & 1 & 0 & -0.000450 & -3.365638 & -1.235534 \\
\hline 9 & 1 & 0 & 0.000618 & -1.238291 & -2.524658 \\
\hline 10 & 1 & 0 & 0.000618 & -1.238291 & 2.524658 \\
\hline 11 & 7 & 0 & -0.000116 & 1.213619 & -1.263594 \\
\hline 12 & 7 & 0 & -0.000116 & 1.213619 & 1.263594 \\
\hline 13 & 16 & 0 & 0.000029 & 2.266669 & 0.000000 \\
\hline
\end{tabular}

Table S-4. Cartesian coordinates for DFT-minimized structure of BTZ ${ }^{*}$.

\begin{tabular}{|c|c|c|c|c|c|}
\hline \multirow{2}{*}{$\begin{array}{l}\text { Center } \\
\text { Number }\end{array}$} & \multirow{2}{*}{$\begin{array}{l}\text { Atomic } \\
\text { Number }\end{array}$} & \multirow{2}{*}{$\begin{array}{l}\text { Atomic } \\
\text { Type }\end{array}$} & \multicolumn{3}{|c|}{ Coordinates (Angstroms) } \\
\hline & & & $x$ & $\mathrm{Y}$ & Z \\
\hline 1 & 6 & 0 & 0.000001 & -2.450438 & 0.702471 \\
\hline 2 & 6 & 0 & 0.000001 & -2.450438 & -0.702471 \\
\hline 3 & 6 & 0 & 0.000000 & -1.250799 & -1.420672 \\
\hline 4 & 6 & 0 & 0.000001 & -0.013984 & -0.730629 \\
\hline 5 & 6 & 0 & 0.000001 & -0.013984 & 0.730629 \\
\hline 6 & 6 & 0 & 0.000000 & -1.250799 & 1.420672 \\
\hline 7 & 1 & 0 & -0.000001 & -3.397837 & 1.241460 \\
\hline 8 & 1 & 0 & -0.000001 & -3.397837 & -1.241460 \\
\hline 9 & 1 & 0 & -0.000002 & -1.245620 & -2.508603 \\
\hline 10 & 1 & 0 & -0.000002 & -1.245620 & 2.508603 \\
\hline 11 & 7 & 0 & -0.000003 & 1.209463 & -1.304516 \\
\hline 12 & 7 & 0 & -0.000003 & 1.209463 & 1.304516 \\
\hline 13 & 16 & 0 & 0.000002 & 2.308568 & 0.000000 \\
\hline
\end{tabular}




\section{Reference}

S1. Gaussian 09, Revision E.01, Frisch, M. J.; Trucks, G. W.; Schlegel, H. B.; Scuseria, G. E.; Robb, M. A.; Cheeseman, J. R.; Scalmani, G.; Barone, V.; Mennucci, B.; Petersson, G. A.; Nakatsuji, H.; Caricato, M.; Li, X.; Hratchian, H. P.; Izmaylov, A. F.; Bloino, J.; Zheng, G.; Sonnenberg, J. L.; Hada, M.; Ehara, M.; Toyota, K.; Fukuda, R.; Hasegawa, J.; Ishida, M.; Nakajima, T.; Honda, Y.; Kitao, O.; Nakai, H.; Vreven, T.; Montgomery, J. A., Jr.; Peralta, J. E.; Ogliaro, F.; Bearpark, M.; Heyd, J. J.; Brothers, E.; Kudin, K. N.; Staroverov, V. N.; Kobayashi, R.; Normand, J.; Raghavachari, K.; Rendell, A.; Burant, J. C.; Iyengar, S. S.; Tomasi, J.; Cossi, M.; Rega, N.; Millam, J. M.; Klene, M.; Knox, J. E.; Cross, J. B.; Bakken, V.; Adamo, C.; Jaramillo, J.; Gomperts, R.; Stratmann, R. E.; Yazyev, O.; Austin, A. J.; Cammi, R.; Pomelli, C.; Ochterski, J. W.; Martin, R. L.; Morokuma, K.; Zakrzewski, V. G.; Voth, G. A.; Salvador, P.; Dannenberg, J. J.; Dapprich, S.; Daniels, A. D.; Farkas, Ö.; Foresman, J. B.; Ortiz, J. V.; Cioslowski, J.; Fox, D. J. Gaussian, Inc., Wallingford CT, 2013. 